\title{
Observations on Catch Composition of Conventional Estuarine Set Bag Nets (CESBN) Operated in Hoogly - Matlah Estuary, West Bengal, India
}

\author{
Olipriya Biswas" and N.A. Talwar
}

Department of Fisheries Engineering, Faculty of Fishery Sciences, WBUAFS, Kolkata, India

*Corresponding author

A B S T R A C T

\begin{tabular}{|l|}
\hline Key w or d s \\
$\begin{array}{l}\text { Set bag net, Finfishes, } \\
\text { Shellfishes, Catch } \\
\text { composition }\end{array}$ \\
\hline Article Info \\
\hline Accepted: \\
23 March 2018 \\
Available Online: \\
10 April 2018 \\
\hline
\end{tabular}

Preliminary studies on conventional estuarine set bag net (CESBN) were carried out during 2016-17 to know the current catch composition. The set bag net is locally fabricated fixed net, normally operated in estuarine region during winter season. The fishing trials were carried out in day time with soaking period of six hours excluding time of setting and hauling. Total of twenty cruises were made for the entire period of study. Results revealed that locally rigged set bag net with $20 \mathrm{~mm}$ bar mesh size at cod end landed average catch composition of $23.15 \mathrm{~kg} /$ haul. The catch consists of fishes such as Herphodon nepherus (14.62\%), Otolithoides pama (5.78\%), Polynemus paradiscus $(2.121 \%)$, Ilisha megaloptera (1.93\%), Trichurus spp (6.42\%), Pampus argenteus (2.89\%), Chirocentrus dorab (1.81\%), Setipinna phasa (4.681\%), Coilia spp (2.521\%), Catfishes $(3.09 \%)$ and shellfishes such as Metapanaeus spp (4.730\%), Peneaus spp (2.350\%), Macrobrachum spp (1.24\%) and Metapenaeus monoceros (6.68\%).

\section{Introduction}

Hooghly-Matlah Estuary, Latitude $20^{\circ} 35^{\prime} \mathrm{N}$ and Longitude $87^{\circ} 45^{\prime} \mathrm{E}$ to Latitude $23^{\circ} 20^{\prime} \mathrm{N}$ and Longitude $89^{\circ} \mathrm{E}$, at southern fringe of the State of West Bengal is a major estuarine complex of the eastern coast of the country with an area of $8029 \mathrm{~km}^{2}$, which has the largest deltaic region in the world with innumerable tributaries and network of creeks.

Its aquatic environment is very rich with quite good number of shellfish and finfish species and several aquatic and terrestrial fauna (Talwar et al., 2013). These natural resources are the chief source of livelihood of deltaic populations and besides, providing proteinaceous food to them. It has a long history of traditional fishing practices.

Fishery exploitation by bag-netter units is a typical feature of the lower zone of the Hoogly estuary, West Bengal, India during winter season from October to February. The number of fishing camps set up at different centres, the fishermen population migrating to different centres, the number of bag nets operated by them and number of mechanized and nonmechanized boats put into operations (Paul et al., 1997).

Conventional estuarine set bag net (CESBN) continued the most dominated gear in the entire estuary, accounting for $74.7 \%$ of the 
total catch of this zone. Total estimated estuarine set bag net landings fluctuated within 2080.6 to 35844.6 tons per season with an average CPUE of 93.72 to $53.12 \mathrm{~kg}$ during the period of 1994-95 to 1999-2000 respectively (Mitra et al., 2001). Though the total catch of estuarine set bag net shows a declining trend, it indicates the warning signal over exploitation. This indicates an urgent need to regulate fishing activities to promote judicious exploitation for sustainable estuarine resources. Several workers have studied the fish and fisheries resources of Hoogly-Matlah estuarine. However, very little work is done on catch composition with respect to bag net design and fabrication parameters of fishing gears and methods in this region.

In this context, a study has been carried out on the current catch composition of conventional set estuarine bag net operated along the estuary to create basic data for improving its design and other engineering parameters like mesh size, mesh shape etc. for sustainable of fishery resources.

\section{Materials and Methods}

Conventional estuarine set bag net was designed and fabricated based on data obtained from survey made by visiting the fishing villages viz. Kakdwip, Namkhana, Fraserganj, Nurpur and Falta and fish landing centres viz. Canning, Kakdwip, Namkhana, Fraserganj, Sagar and Diamond Harbour through questionnaires, interviews and the specifications of fishing gears were checked and recorded in the field itself especially along the belt of Hoogly-Matlah estuary. The details of specifications are given in table 1 and figure 1 and are presented as per the fishing gear catalogue (FAO, 1972).

The fishing trials were carried out in day time, along the lower estuarine belt, the fishing grounds were chosen based on the other local bag-net operators with reference to depth and direction successively.

The net was fixed (set) in the tidal stream of lower estuary against the currents by linking their extended sides of net (wing tips). These wing tips were fastened to holdfasts by means of 16 metres long bamboo poles and 4 metres steel wires. The two wooden stake holdfasts used were embedded some distance apart in the estuarine bed, so that the net is parallel to the direction of the current. The duration of soaking was fixed at six hours excluding period of setting and hauling of net.

After six hours of hauling, the catch obtained was sorted out into finfishes, shell fishes and by catches. Species identification was made on field itself based on FAO species identification sheet and the existing artisanal fishing gears and methods were classified according to Von Brandt A classification (FAO, 1972).

Catching efficiency of the net was judged after testing the significant difference between the total catches by weight obtained in the net. This was done by Mann Whitney ' $U$ ' test (Weber, 1973; Daniel, 1977).

\section{Results and Discussion}

Total twelve-day fishing trails CESBN were made during the period from last week of November 2016 to middle of February 2017. The fishing days were chosen based on the full moon and new moon with an interval of fortnight and four hauls were made in each day of sampling with an average time of 6 hours is maintained for soaking nets. The total forty-eight hauls were made in twelve-day sampling. The catch obtained was grouped into fin fishes and shellfishes that together constitute the total commercial group. The catch of undersized, juveniles of commercial group and other miscellaneous fishes were 
grouped as by-catch. The total weight of each finfish and shellfish group and their different species of sample groups were recorded.

\section{Total catch analysis}

Total catch by weight obtained during each haul of six-hour duration for CESBN are tabulated in Table 2. The highest catch rates were observed in the last day of sampling in the month of December with the peak catch of $118.2 \mathrm{~kg}$. The lowest catch of CESBN was $69.81 \mathrm{~kg}$, recorded in the last day of sampling (i.e., in month of February). The average catch rate of CESBN was $23.15 \mathrm{~kg} / \mathrm{haul}$ in the entire period of sampling. This could be due to the south-west monsoon influences West Bengal's fisheries to a great extent. The peak season is during the fair-weather period, from midOctober to end-February (FAO, 1990).

Meanwhile the coastal zone of West Bengal especially at estuary region contained large amount of organic matters, detritus and other washed-off materials, that is rich in nutrients and this is deposited above and below the mouth of the estuary during monsoon by heavy inflow in the streams (Dutta, 1973).

This brings about major change in the food chain by inducing a rich growth of phytoplankton, which reaches a peak in winter months. Such conditions are highly prevalent in the shallow sea surface regions of this bay where the bag net fishery operates (Mitra et al., 1987).

The highest quantity of fish catch was recorded during the month of December. It was also observed that there was a gradual increase in the catch rate per haul during the period of study from the month of November to December. Again, it was observed that a gradual decrease in catch rate per haul was recorded till the end of hauling period from month of January to February.
Based on these reports, we could interpret that, increased abundance of catch from November to February with peak in December month in both nets could be mainly due to the winter bloom of plankton causing a feeding and breeding migration of finfishes and shellfishes in the coastal region. This may induce migration of their predators as well. Similar results have been reported by Talwar (2004) during his studies on design, construction and development of Eco Behundi Jal in relation to conservation of Fish resources of Sundarban Estuary, West Bengal.

\section{Catch composition}

The catch obtained in CESBN during period of study was grouped into fin fishes, shellfishes and by-catches for the purpose of analysis. The percentage composition of different finfishes, shellfishes and by-catch and their total catch rates obtained in CESBN are presented in Table 3.

The catches comprised 12 and 5 species of commercially important finfishes and shellfishes respectively. Among fin fishes, eleven species of finfishes namely, Coilia spp., Setipinna phasa, Setipinna taty, Herphodon neherus, Osteogenious militoris, Otolithoides pama, Cynoglassus spp., Pampus argenteus, Trichiurus spp., Ilisha megaloptera, Polynemus paradiseus and Chirocentrus dorab are marine species.

In shellfish group, five (5) shrimps namely Metapenaeus monocereos, Metapenaeus spp. Peneaus spp. and Parapenaeopsis spp. are marine forms and other one (1) species namely Macrobrachium spp. is freshwater prawn. Many workers have reported similar species-wise catch composition during their exploitation in lower zone of estuary by bag net (Pillay and Ghosh, 1962; Dutta, 1973; Mitra et al., 1987; Talwar, 2004; Talwar et al., 2014). 
Table.1 Specifications for Conventional Estuarine Set Bag Net (CESBN)

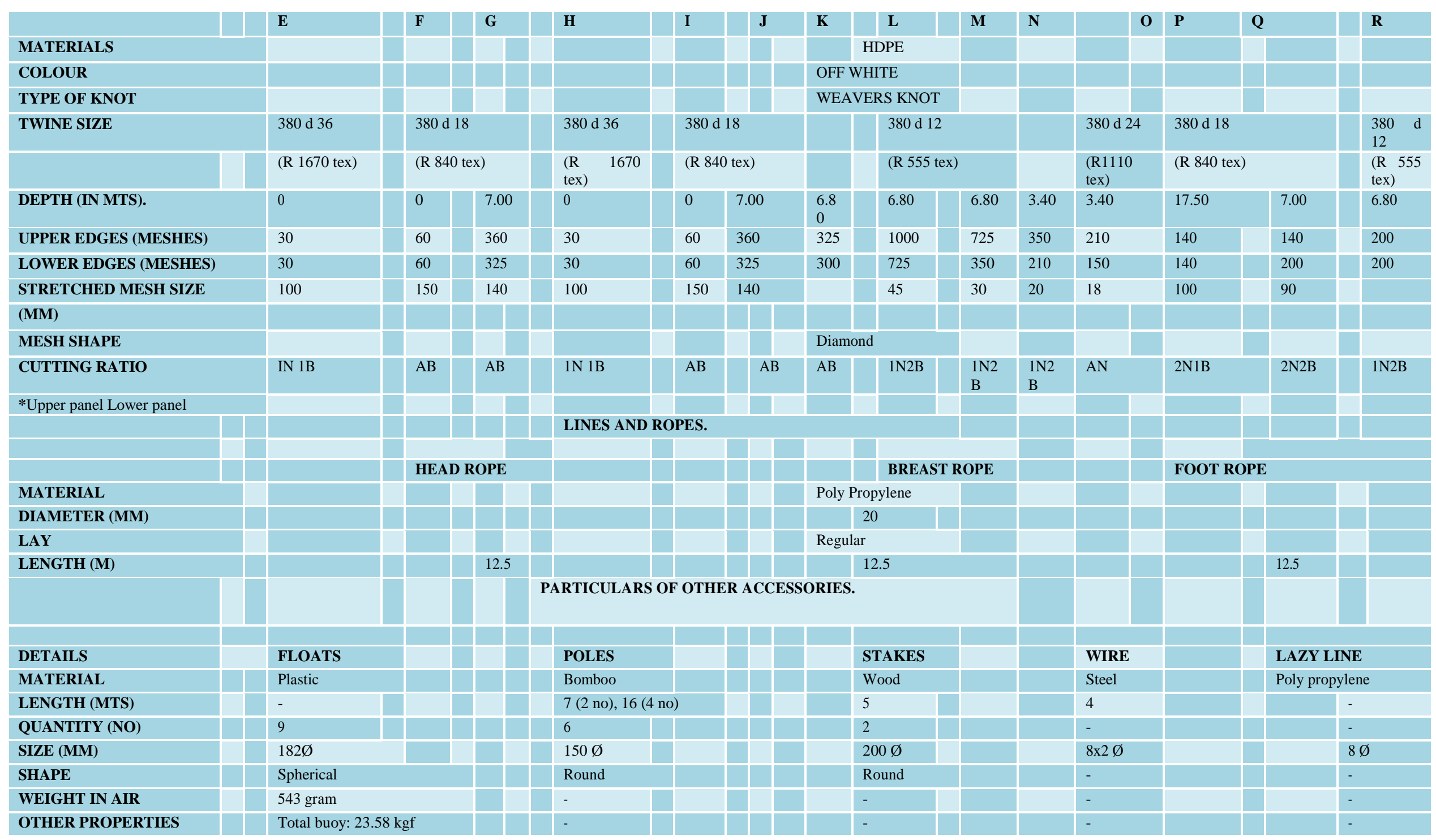


Table.2 Total catch (weight) obtained during each haul of six (6) hours duration in CESBN

\begin{tabular}{|c|c|c|c|c|c|}
\hline $\begin{array}{l}\text { Date of } \\
\text { sampling }\end{array}$ & $\begin{array}{l}\text { Haul } \\
\text { No }\end{array}$ & $\begin{array}{l}\text { Total catch } \\
(\mathrm{kg} / \mathrm{haul})\end{array}$ & $\begin{array}{l}\text { Date of } \\
\text { sampling }\end{array}$ & $\begin{array}{l}\text { Haul } \\
\text { No }\end{array}$ & $\begin{array}{l}\text { Total catch } \\
\text { (kg/haul) }\end{array}$ \\
\hline \multirow[t]{5}{*}{ 29.11.2016 } & 1 & 27.75 & \multirow[t]{5}{*}{14.1 .2017} & 1 & 32.25 \\
\hline & 2 & 26.25 & & 2 & 30.50 \\
\hline & 3 & 18.75 & & 3 & 21.80 \\
\hline & 4 & 6.75 & & 4 & 7.85 \\
\hline & Total & 79.5 & & Total & 92.4 \\
\hline \multirow[t]{5}{*}{30.11 .2016} & 1 & 30.2 & \multirow[t]{5}{*}{15.1 .2017} & 1 & 33.55 \\
\hline & 2 & 28.6 & & 2 & 31.75 \\
\hline & 3 & 20.4 & & 3 & 22.65 \\
\hline & 4 & 7.35 & & 4 & 8.26 \\
\hline & Total & 86.55 & & Total & 96.21 \\
\hline \multirow[t]{5}{*}{ 15.12.2016 } & 1 & 35.75 & \multirow[t]{5}{*}{ 29.01.2017 } & 1 & 31.7 \\
\hline & 2 & 33.80 & & 2 & 30.00 \\
\hline & 3 & 24.15 & & 3 & 21.4 \\
\hline & 4 & 8.70 & & 4 & 7.7 \\
\hline & Total & 102.4 & & Total & 90.8 \\
\hline \multirow[t]{5}{*}{16.12 .2016} & 1 & 34.65 & \multirow[t]{5}{*}{30.01 .2017} & 1 & 30.90 \\
\hline & 2 & 32.8 & & 2 & 29.25 \\
\hline & 3 & 23.4 & & 3 & 20.9 \\
\hline & 4 & 8.45 & & 4 & 7.5.00 \\
\hline & Total & 99.3 & & Total & 88.55 \\
\hline \multirow[t]{5}{*}{30.12 .2016} & 1 & 39.2 & \multirow[t]{5}{*}{15.02 .2017} & 1 & 26.25 \\
\hline & 2 & 37 & & 2 & 25.00 \\
\hline & 3 & 26.4 & & 3 & 17.4 \\
\hline & 4 & 9.5 & & 4 & 6.81 \\
\hline & Total & 112.1 & & Total & 75.46 \\
\hline \multirow[t]{5}{*}{31.12 .2016} & 1 & 41.25 & \multirow[t]{5}{*}{ 16.02.2017 } & 1 & 24.31 \\
\hline & 2 & 38.95 & & 2 & 23.00 \\
\hline & 3 & 27.85 & & 3 & 16.5 \\
\hline & 4 & 10.15 & & 4 & 6.00 \\
\hline & Total & 118.2 & & Total & 69.81 \\
\hline & & $\begin{array}{l}\text { Grand } \\
\text { Total }\end{array}$ & 1111.28 & & \\
\hline & & Average & 23.15 & & \\
\hline
\end{tabular}


Table.3 Percentage composition of catch (weight) obtained CESBN

\begin{tabular}{|c|c|c|c|c|}
\hline S1. No. & & NAME OF FISHES & Wt. in $\mathrm{kg}$ & $\%$ \\
\hline A & \multicolumn{2}{|c|}{ FIN FISHES } & & \\
\hline \multirow[t]{4}{*}{1} & \multicolumn{2}{|c|}{ Anchovies } & & \\
\hline & a) & Coilia spp. & 28.015 & 2.521 \\
\hline & b) & Setipinna phasa & 52.019 & 4.681 \\
\hline & c) & Setipinna taty & 35.894 & 3.23 \\
\hline \multirow[t]{2}{*}{2} & \multicolumn{2}{|c|}{ Bombay duck } & & \\
\hline & \multicolumn{2}{|c|}{ Herphodon neherus } & 162.469 & 14.62 \\
\hline \multirow[t]{2}{*}{3} & \multicolumn{2}{|c|}{ Cat fishes } & & \\
\hline & \multicolumn{2}{|c|}{ Osteogenious militoris } & 22.081 & 1.987 \\
\hline \multirow[t]{2}{*}{4} & \multicolumn{2}{|c|}{ Croakers (Sciaenids) } & & \\
\hline & \multicolumn{2}{|c|}{ Otolithoides pama } & 64.232 & 5.78 \\
\hline \multirow[t]{2}{*}{5} & \multicolumn{2}{|c|}{ Flat fishes (soles) } & & \\
\hline & \multicolumn{2}{|c|}{ Cynoglossuss spp. } & 36.906 & 3.321 \\
\hline \multirow[t]{2}{*}{6} & \multicolumn{2}{|c|}{ Pomfrets } & & \\
\hline & \multicolumn{2}{|c|}{ Pampus argenteus } & 32.116 & 2.89 \\
\hline
\end{tabular}


Int.J.Curr.Microbiol.App.Sci (2018) 7(4): 2681-2691

\begin{tabular}{|c|c|c|c|c|}
\hline 7 & \multicolumn{2}{|c|}{ Ribbon fishes } & & \\
\hline & \multicolumn{2}{|c|}{ Trichiurus spp } & 71.344 & 6.42 \\
\hline \multirow[t]{2}{*}{8} & \multicolumn{2}{|c|}{ Shads (clupeids) } & & \\
\hline & \multicolumn{2}{|c|}{ Ilisha megaloptera } & 21.448 & 1.93 \\
\hline \multirow[t]{2}{*}{9} & \multicolumn{2}{|c|}{ Threadfins (Polynemids) } & & \\
\hline & \multicolumn{2}{|c|}{ Polynemus paradiscus } & 23.570 & 2.121 \\
\hline \multirow[t]{3}{*}{10} & \multicolumn{2}{|c|}{ Wolf herrings } & & \\
\hline & \multicolumn{2}{|c|}{ Chirocentrus dorab } & 20.114 & 1.81 \\
\hline & \multicolumn{2}{|c|}{ Sub Total } & 570.209 & 51.311 \\
\hline \multirow[t]{7}{*}{ B. } & \multicolumn{2}{|c|}{ SHELL FISHES } & & \\
\hline & a) & Metapanaeus monoceros & 74.234 & 6.680 \\
\hline & b) & Metapanaeus spp & 52.564 & 4.730 \\
\hline & c) & Peneaus spp. & 26.115 & 2.350 \\
\hline & d) & Parapenaeopsis spp & 44.118 & 3.970 \\
\hline & e) & Macrobrachum spp & 13.780 & 1.240 \\
\hline & $\mathrm{Su}$ & Total & 210.810 & 18.970 \\
\hline C. & Mi & ellaneous (By-catch) & 330.260 & 29.719 \\
\hline & $\mathrm{Gr}$ & Total $(A+B+C)$ & 1111.28 & 100 \\
\hline
\end{tabular}


Fig.1 Dimensions and construction characteristics of Conventional Estuarine Set Bag net (CESBN)

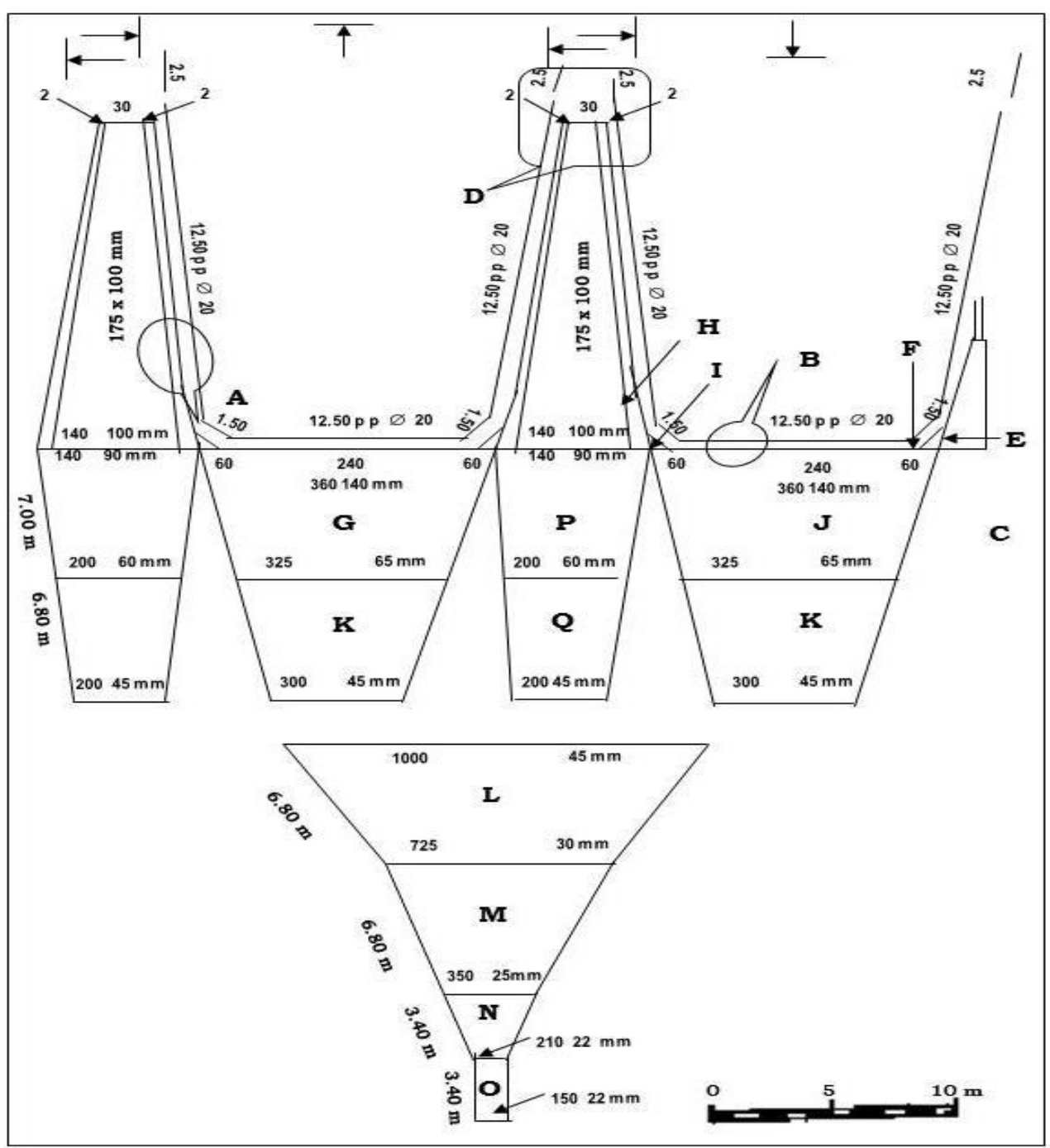




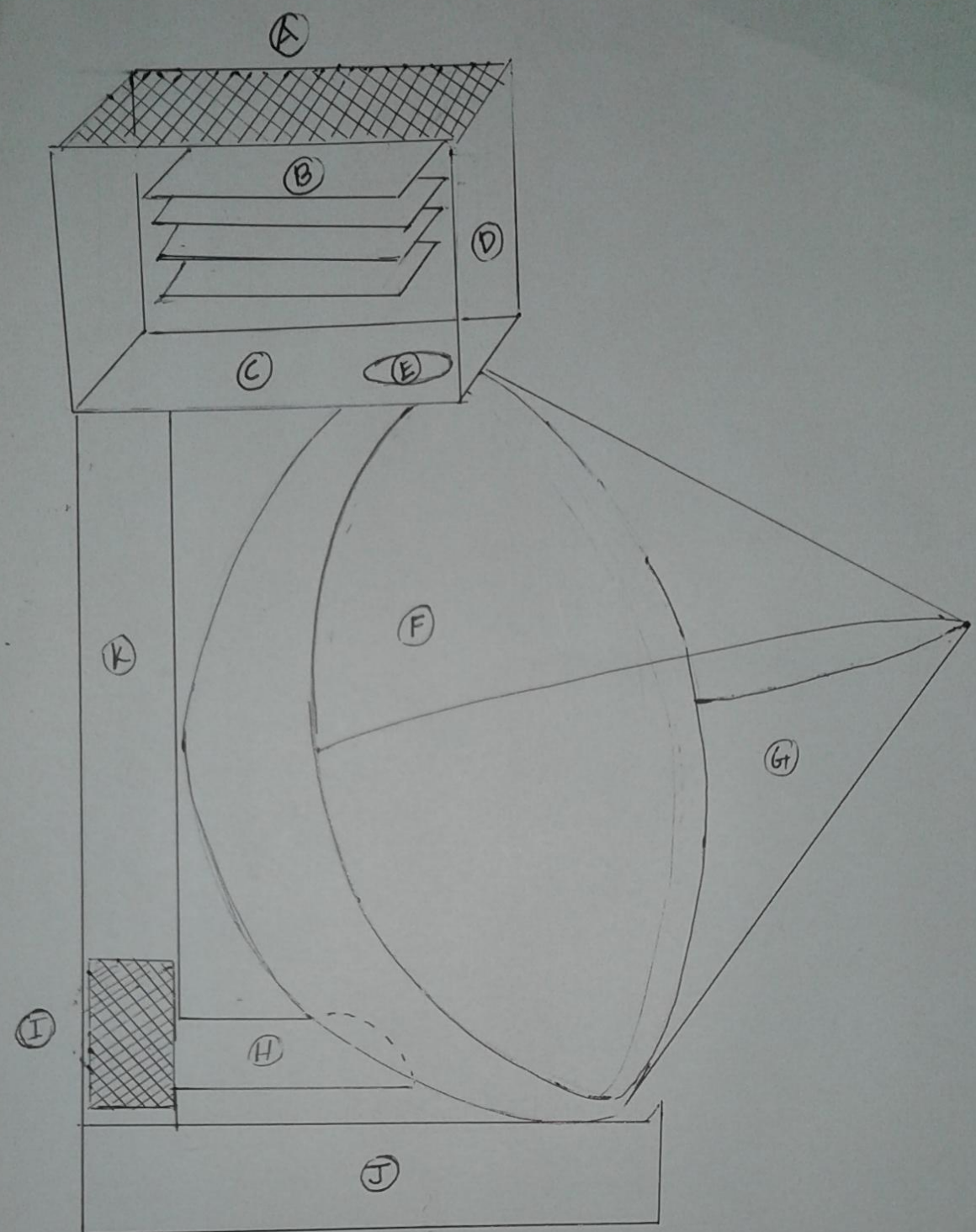
(A) - Air outlet (Wire Mesh).(B)- Dryertray (C) Alurivium sheet in Dryer

(D) Poly theneshectin Dryer Chamber (E) Air outlet (Hot Air)

(E) Parabolic Disc (Aluminium covered sheet), (G)-Poly thene sheet (A) Air inlet pipe (Cdd Air), (I) Air Inlet (Wire Mesh), (T)-Base (1) - stand.

$$
\begin{aligned}
& \text { Figure: Improvised Solar Dryer Using } \\
& \text { Concentrating Solar (cs) Technology. }
\end{aligned}
$$


The total catch $(\mathrm{kg})$ of finfishes was highest in CESBN $(570.20 \mathrm{~kg})$ followed by miscellaneous catch (by-catch) (i.e., about $330.26 \mathrm{~kg})$ and shellfishes $(210.81 \mathrm{~kg})$. Among the finfish species groups Bombay duck (Herphodon neherus) recorded highest catch $(162.46 \mathrm{~kg})$ followed by Ribbon fishes (Trichiurus spp.) $(71.34 \mathrm{~kg})$ and Croakers $(64.23 \mathrm{~kg})$.

In shellfish group, five species were recorded in CESBN during the period of study. Among them, the total catch landed, Metapenaeus monoceros is highest $(74.23 \mathrm{~kg}$ ) followed by, Metapenaeus spp. (52.56kg), Parapenaeopsis spp. $(44.11 \mathrm{~kg})$, Peneaus spp. $(26.11 \mathrm{~kg})$, and Macrobrachium spp. $(13.78 \mathrm{~kg})$. The contribution of the commercial groups of fin fishes to the total catch was $51.31 \%$ in CESBN. Bombay duck (Herphodon neherus) dominated with $14.62 \%$ of total catch. Ribbon fishes, Trichiurus spp. was second dominant species contributing to $6.42 \%$. Anchovies group, consisting three species namely, Coilia spp. Setipinna phasa and Setipinna taty was the second most dominant finfishes group contributing total of $10.43 \%$ in CESBN. The catch of shellfish group was only $18.87 \%$. Among the shell fishes group, the catch of Metapenaeus monoceros was higher. The Peneaus spp catch was only $2.35 \%$. The Metapenaeus spp. catch was only $7.43 \%$ in CESBN. Parapenaeopsis spp. also contributed good share of the total catch (3.97\%). Macrobrachium spp. contributed comparatively less share of the total catch $(1.24 \%)$ in CESBN.

The higher percentage of finfish composition could be mainly due to the reduction of bycatch in CESBN.

Many workers have reported similar specieswise catch compositions as well as percentage wise during their exploitation of lower zone of estuary by winter migrating bag net (Pillay and Ghosh, 1962; Dutta, 1973; Mitra et al., 1987).

The average catch rate of CESBN was $23.15 \mathrm{~kg}$ per day sampling haul. The highest catch rates were observed in the last day of sampling in the month of December with the peak catch of $118.2 \mathrm{~kg}$. The lowest catch of CESBN was $69.81 \mathrm{~kg}$, recorded in the last day of sampling (i.e., in month of February). The average catch rate of CESBN was 23.15 $\mathrm{kg} / \mathrm{haul}$ in the entire period of sampling. This could be due to the south-west monsoon influences West Bengal's fisheries to a great extent. The catch rates of commercially valuable species constituted a higher percentage of the total catch of CESBN (70.28\%) during the period of sampling. The catches comprised 12 and 5 species of commercially important fin fishes and shellfishes respectively. Among fin fishes, eleven species of fin fishes namely, Coilia spp., Setipinna phasa, Setipinna taty, Herphodon neherus, Osteogenious militoris, Otolithoides pama, Cynoglassus spp., Pampus argenteus, Trichiurus spp., Ilisha megaloptera, Polynemus paradiseus and Chirocentrus dorab are marine species. In shellfish group, five (5) shrimps namely Metapenaeus monocereos, Metapenaeus spp. Peneaus spp. and Parapenaeopsis spp. are marine forms and other one (1) species namely Macrobrachium spp. is freshwater prawn.

\section{References}

Daniel, W. W. (1977). Introductory statistics with Application. Houghton Miff on Company London: 473.

Dutta, S. N. (1973). On the gill nets of the Hooghly-Matla estuarine system (West Bengal) with special reference to their specification and operation. Journal of Inland Fisheries Society of India 5:2936. 
FAO (1990), www.fao.org

FAO, (1972). Food and Agriculture Organization of the United Nations. Fishing Gear and Methods Branch (1972). FAO catalogue of fishing gear designs. : Catalogue FAO de plans d engins de pêche ([Rev. ed.]). Fishing News, West Byfleet.

Mitra, P. M., Ghosh, K. K., Saigal, B. N., Sarkar, N. D., Roy, A. K., Mondal, N. C. and Paul, A. R. (1987). Fishing gear of the upper and middle Hooghly estuary. Technical Bulletin No. 49. Central Inland Fisheries Research Institute, Barrackpore, India. $22 \mathrm{p}$.

Mitra, P. M., Karmakar, H. C., Ghosh, A. K., Mandal, N. C., Sen, H. K. and Das, B. N. (2001). Fisheries of Hooghly Matlah Estuarine System: Further Appraisal (1994-95 to 1999-2000). Bulletin No. 109.

Paul, S., Mitra, P. M., De, D. K., Sen, H. K., Mandal, N. C. and Singh, P. (1997). Winter migratory bagnet fishery of the Hooghly estuary-an economic evaluation. Technical Bulletin No. 76 . Central Inland Fisheries Research Institute, Barrackpore, India. 15p.

Pillay, T. V. R. and Ghosh, K. K. (1962). The bag net fishery of the Hooghly-Matlah estuarine system (West Bengal). Indian Journal of Fisheries (9A):71-99.

Talwar (2004). Studies on design, construction and development of ecobehundi jal' in relation to conservation of fish resources of sunderban estuary, West Bengal. Karnatak University, Karwar-581 301, India.

Talwar, N.A., Banerjee, S.P., Chakraborty, S., (2014), Catching Efficiency Of Artisanal Estuarine Winter Migratory Bag Net (EWMBN) Operated Along Hooghly - Matlah Estuary, West Bengal, India. International Journal of Scientific \& Technology Research, 2(7): 86-91.

Weber. R., (1973) Non-parametric methods. Biostatistics in Pharmacology, Dehaunois, A.L(Ed), and Pergamun. Press (New York); 2: 675- 716.

\section{How to cite this article:}

Olipriya Biswas and Talwar, N.A. 2018. Observations on Catch Composition of Conventional Estuarine Set Bag Nets (CESBN) Operated in Hoogly - Matlah Estuary, West Bengal, India. Int.J.Curr.Microbiol.App.Sci. 7(04): 2681-2691. doi: https://doi.org/10.20546/ijcmas.2018.704.306 